\title{
Joanna Nucińska
}

Katolicki Uniwersytet Lubelski Jana Pawła II e-mail: joanna.nucinska@kul.pl

\section{SYSTEM INFORMACJI OŚWIATOWEJ JAKO SYSTEM POMIARU DOKONAŃ EDUKACYJNYCH W KONTEKŚCIE OCENY EFEKTYWNOŚCI PUBLICZNEGO FINANSOWANIA OŚWIATY W POLSCE}

\section{EDUCATIONAL INFORMATION SYSTEM AS A SYSTEM OF EDUCATION PERFORMANCE MEASUREMENT IN THE CONTEXT OF ASSESSING THE EFFICIENCY OF PUBLIC FUNDING FOR EDUCATION IN POLAND}

DOI: $10.15611 /$ pn.2017.472.28

JEL Classification: H83, I22

Streszczenie: Obiektem badań był zbiór danych o efektach edukacyjnych, gromadzonych w systemie informacji oświatowej (SIO). Za cel badawczy przyjęto jego analizę i ocenę przydatności jako źródła danych dla mierników efektywności budżetu zadaniowego. Realizacja celu wymagała krytycznej analizy prawa krajowego i literatury dotyczącej pomiaru dokonań. Przeanalizowano także dane ze sprawozdań z wykonania budżetów wybranych samorządów w układzie zadaniowym pod kątem wykorzystania danych SIO jako mierników realizacji zadań oświatowych. Z przeprowadzonych badań wynika, iż SIO dostarcza bogatego zasobu danych edukacyjnych, które są gromadzone obowiązkowo i podlegają weryfikacji. Mógłby więc mierzyć dokonania na potrzeby budżetu zadaniowego, jednak w praktyce istotnym problemem jest rozbieżność czasowa danych SIO (stan na 30 września; rok szkolny) i danych finansowych budżetu (rok kalendarzowy). Artykuł jest częścią cyklu publikacji pt. „Uwarunkowania pomiaru efektywności finansowania edukacji”.

Słowa kluczowe: pomiar dokonań, system informacji oświatowej, budżet zadaniowy, ekonomika edukacji.

Summary: The data set on the effects of education, gathered in the Educational Information System (EIS) is the object of this study. The article presents the scope of EIS and the assessment of its usefulness for efficiency measures in performance budget. The author analizes national law, the literature on performance measurement and budget implementation reports of some local governments in Poland with performance budgets. The study shows that the EIS provides 
a rich data resource on educational effects with mandatory data collection and verification. It might therefore carry out the measurement of achievements for performance budget, but time discrepancy of EIS data (state at 30 September, the school year) and financial data in local budgets (the calendar year) is quite asignificant disadvantage of EIS. This research paper is a part of the publications series entitled "Conditioning of measuring the efficiency of education funding".

Keywords: performance measurement, Educational Information System, performance budget, economics of education.

\section{Wstęp}

Potrzeba oceny efektywności finansowania oświaty ze środków publicznych wynika z wymogów ustawy [Ustawa z 27 sierpnia 2009, art. 44] dotyczących wydatków publicznych, w tym: wydatków ponoszonych przez jednostki samorządu terytorialnego (dalej: JST), które realizują większość zadań oświatowych w Polsce. Ustawodawca nałożył na dysponentów środków publicznych (w sposób pośredni) obowiązek mierzenia efektów wydatkowania środków oraz ustalania przyczyn nieosiągnięcia zaplanowanego poziomu efektów. Wymaga to pomiaru dokonań w sektorze finansów publicznych, a system ich pomiaru powinien informować, jakie efekty są związane z ponoszonymi wydatkami [Filipiak 2011, s. 160-161], m.in. na oświatę.

$\mathrm{W}$ artykule podjęto próbę odpowiedzi na pytanie, czy polski system informacji oświatowej (dalej: SIO) spełnia warunki definicji systemu pomiaru dokonań i wymagania stawiane takim systemom w zakresie pomiaru wydajności (w tym: efektywności publicznego finansowania oświaty). Ponadto poddano ocenie wykorzystanie danych SIO do konstrukcji mierników w budżecie zadaniowym, określanym jako instrument pomiaru dokonań [Filipiak 2011].

\section{Pojęcie oraz istota systemu pomiaru dokonań}

Pomiar dokonań należy do dynamicznie rozwijających się obszarów rachunkowości zarządczej [Kowalewski 2011, s. 249], jednak w literaturze przedmiotu nie wypracowano na razie jednej powszechnie przyjętej definicji ani dokonania, ani systemu pomiaru dokonań.

Słowo dokonanie stanowi odpowiednik angielskiego określenia performance.

A.M. Kostur definiuje dokonanie jako [Buk, Kostur (red.) 2009, s. 151-152]:

- miarę (liczbę) lub wyrażenie umożliwiające komunikację zarządzającym,

- kreowanie wartości w wyniku działania,

- efekt celowej (zamierzonej) działalności,

- zdolność (potencjał) do tworzenia efektów w przyszłości,

- osiągnięcia organizacji na tle wzorca. 
Dokonanie może być rozumiane statycznie (jako wydarzenie, efekt), dynamicznie (jako działanie) lub - najpełniej - symultanicznie (jako działanie wraz z efektem działania). Podmiot, który zamierza zarządzać swoimi dokonaniami, musi sprecyzować ich definicję, sposób pomiaru i oceny, ponieważ „dokonania istnieją, gdy efekty i rezultaty mogą być opisane lub zmierzone i zakomunikowane odbiorcom w celu podjęcia decyzji” [Buk, Kostur (red.) 2009, s. 152-153].

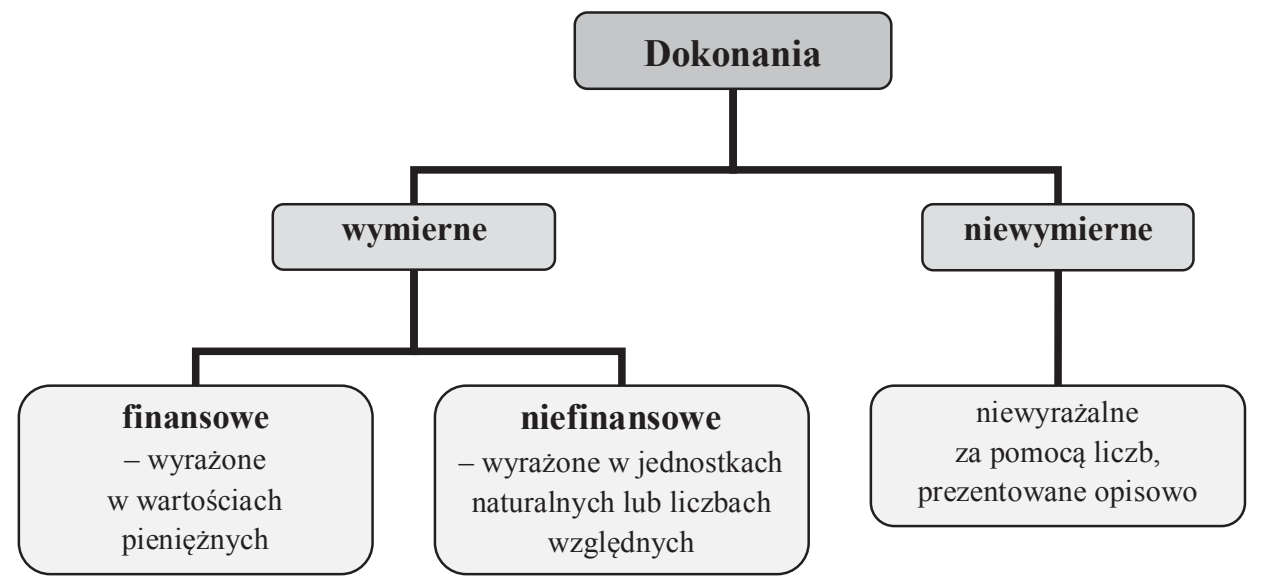

Rys. 1. Klasyfikacja dokonań według możliwości ich pomiaru

Źródło: opracowanie własne na podstawie [Napiecek 2013, s. 77].

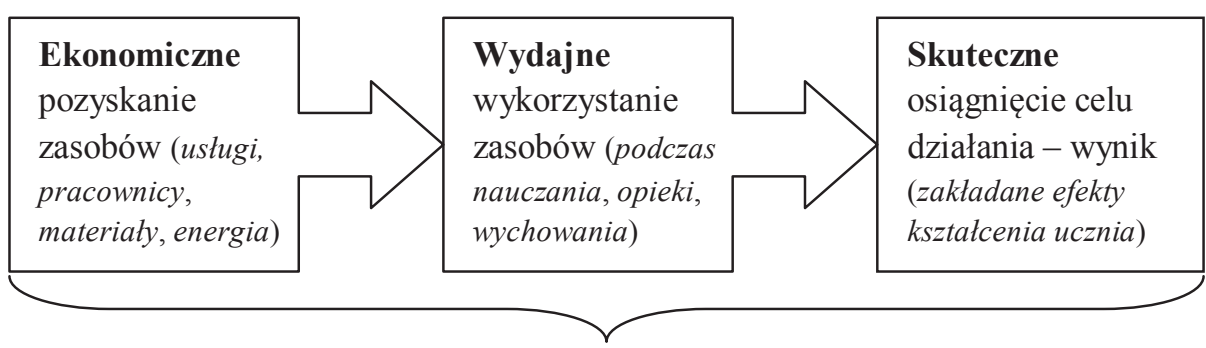

Dokonania jednostki oświatowej

Pomiar dokonań w obszarze oszczędności: jak najniższe wydatki na nakłady o określonym standardzie jakości
Pomiar dokonań w obszarze wydajności: relacja efektów do nakładów lub relacja efektów do wydatków
Pomiar dokonań w obszarze skuteczności: jakość / stopień realizacji zadania lub osiągnięcia celu

Rys. 2. Obszary pomiaru dokonań jednostek oświatowych

Źródło: opracowanie własne na podstawie [Buk, Kostur (red.) 2009, s. 230; Nieplowicz 2011, s. 356]. 
A. Nelly, M. Kennerley i Ch. Adams obejmują pomiarem dokonań efektywność, skuteczność i wydajność przeszłych działań [Kowalewski 2011, s. 249]. Zdaniem A. Karmańskiej pomiar dokonań może skupiać się albo jedynie na miarach finansowych $^{1}$, albo na samych miarach operacyjnych, albo być systemem mieszanym, łącząc oba typy mierników dokonań [Filipiak 2011, s. 161]. Ze względu na kryterium możliwości przeprowadzenia pomiaru, wyróżniamy także dokonania niewymierne (rys. 1), opisywane „niekwantytatywnie” [Buk, Kostur (red.) 2009, s. 221].

Ze względu na szeroki zakres znaczeniowy dokonań jako kategorii ekonomicznej oraz brak jednolitej interpretacji terminologii dotyczącej pomiaru dokonań w literaturze ${ }^{2}$, warto nakreślić obszary ich pomiaru (rys. 2). Nie powinno się jednak pomiaru dokonań utożsamiać wyłącznie z jednym z tych obszarów.

Rozważając zagadnienie pomiaru dokonań instytucji edukacyjnych tworzących polski system oświaty, trzeba przeanalizować obszary przedstawione na rysunku 2. Dokonania publicznych szkół i placówek oświatowych oraz ich organów prowadzących (głównie JST) w ramach pierwszego obszaru dotyczą ekonomicznego pozyskiwania zasobów niezbędnych do działalności. Wskazane podmioty szukają oszczędności (minimalizują wydatki) podczas zakupu dóbr i usług w wymaganej ilości i jakości oraz przy zatrudnianiu pracowników o niezbędnych kwalifikacjach. Drugi obszar dokonań jednostek oświatowych koncentruje się na wydajności wykorzystania zasobów w czasie działań edukacyjnych, opiekuńczych i wychowawczych nastawionych na uzyskanie określonego wyniku. Jednostki dążą zatem do właściwej organizacji działalności, aby zaangażowane w nią zasoby (nakłady, na które ponoszą wydatki) przyczyniały się do osiągnięcia jak najlepszych efektów. Ostatni obszar obejmuje pomiar dokonań w zakresie skuteczności działań podjętych celowo, z zamiarem osiągnięcia zakładanego efektu. Jednostki systemu oświaty analizują stopień i jakość uzyskanych rezultatów na tle planowanych wyników.

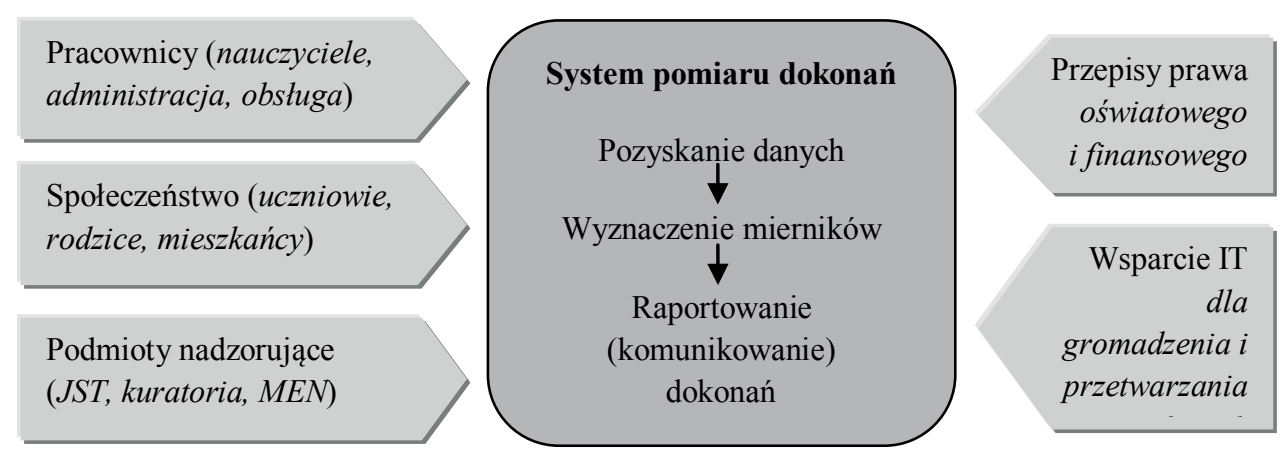

Rys. 3. Wpływ otoczenia na system pomiaru dokonań edukacyjnych

Źródło: opracowanie własne na podstawie [Kotłowska, Kowalak 2016, s. 18].

1 Jednoczenie weryfikując je i doskonaląc.

2 Na co zwracają uwagę m.in. B. Nita [Buk, Kostur (red.) 2009, s. 227-230] i M. Kowalewski [2011, s. 249]. 
Pomiar dokonań umożliwia osobom zarządzającym daną organizacją podejmowanie decyzji opartych na wiarygodnych informacjach o miarach efektywności, skuteczności i wydajności prowadzonej działalności. W literaturze podkreśla się jednak formalne aspekty doboru, pozyskiwania i gromadzenia danych do konstrukcji mierników [Kowalewski 2011, s. 249]. Mówimy wówczas o systemie pomiaru dokonań, którego celem jest przetwarzanie zebranych danych i generowanie (raportowanie, komunikowanie) informacji o dokonaniach podmiotu (rys. 3).

Każda organizacja funkcjonuje w pewnym otoczeniu, które wpływa zarówno na jej działalność, jak i na system pomiaru jej dokonań. Na rysunku 3 przedstawiono główne uwarunkowania oświaty w Polsce, które wpływają na system pomiaru dokonań edukacyjnych - niezależnie od instrumentu prowadzenia pomiaru.

\section{SIO i podmioty zobowiązane do jego prowadzenia}

System informacji oświatowej (SIO) jest zorganizowany i działa w sposób określony w ustawie [Ustawa z 15 kwietnia 2011]. Składa się on z systemu teleinformatycznego oraz z prowadzonych w nim baz danych SIO: „,entralnej” i „lokalnych” (art. 2). Tabela 1 przedstawia charakterystykę i strukturę obu typów baz danych SIO.

Tabela 1. Porównanie baz danych w systemie informacji oświatowej (SIO)

\begin{tabular}{|c|c|c|}
\hline Typ bazy danych & Centralna & Lokalna \\
\hline Administrator & Minister Edukacji Narodowej & $\begin{array}{l}\text { Kierownik jednostki zobowiązanej } \\
\text { do prowadzenia bazy danych SIO }\end{array}$ \\
\hline \multirow[t]{2}{*}{$\begin{array}{l}\text { Możliwość } \\
\text { wymiany danych } \\
\text { z innymi bazami }\end{array}$} & $\begin{array}{l}\text { Pozyskiwanie danych z: } \\
\text { lokalnych baz danych SIO, rejestrów } \\
\text { PESEL i REGON, geoportalu infrastruktu- } \\
\text { ry informacji przestrzennej }\end{array}$ & $\begin{array}{l}\text { Pozyskiwanie danych z: } \\
\text { centralnej bazy danych SIO } \\
\text { lub za pośrednictwem tej bazy }\end{array}$ \\
\hline & $\begin{array}{l}\text { Przekazywanie danych do: } \\
\text { lokalnych baz danych SIO }\end{array}$ & $\begin{array}{l}\text { Przekazywanie danych do: } \\
\text { centralnej bazy danych SIO }\end{array}$ \\
\hline \multirow{4}{*}{$\begin{array}{l}\text { Struktura bazy } \\
\text { danych } \\
\text { (ze wskazaniem } \\
\text { zbiorów w bazach } \\
\text { lokalnych SIO } \\
\text { odpowiadają- } \\
\text { cych zakresem } \\
\text { danych zbiorom } \\
\text { w centralnej bazie } \\
\text { danych SIO) }\end{array}$} & $\begin{array}{l}\text { Rejestr Szkół i Placówek Oświatowych } \\
\text { (RSPO) - zbiór danych o szkołach } \\
\text { i placówkach oświatowych i ich zespołach } \\
\text { Zbiory danych szkól i placówek oświa- } \\
\text { towych - innych danych niż objęte RSPO } \\
\end{array}$ & $\begin{array}{l}\text { Zbiór danych o szkole lub } \\
\text { placówce oświatowej* }\end{array}$ \\
\hline & $\begin{array}{l}\text { Zbiory danych jednostek - zbiory } \\
\text { danych o innych jednostkach } \\
\text { wykonujących zadania z zakresu oświaty }\end{array}$ & $\begin{array}{l}\text { Zbiór danych o innej jednostce } \\
\text { wykonującej zadania z zakresu } \\
\text { oświaty* }\end{array}$ \\
\hline & Zbiory danych o uczniach & Zbiory danych o uczniach** \\
\hline & Zbiory danych o nauczycielach & Zbiory danych o nauczycielach*** \\
\hline
\end{tabular}

* Dla lokalnej bazy danych prowadzonej przez taką jednostkę; ** dla lokalnej bazy danych prowadzonej przez podmiot zobowiązany do przekazywania źródłowych lub przetworzonych danych uczniów do centralnej bazy danych SIO (lub uprawniony do pozyskiwania danych uczniów z tej bazy / za jej pośrednictwem); *** dla lokalnej bazy danych prowadzonej przez podmiot zobowiązany do przekazywania danych nauczycieli do centralnej bazy danych SIO (lub uprawniony do pozyskiwania danych nauczycieli z tej bazy / za jej pośrednictwem).

Źródło: opracowanie własne na podstawie [Ustawa z 15 kwietnia 2011, art. 2, 4-7a]. 
Do prowadzenia lokalnych baz danych SIO zobowiązane zostały następujące podmioty [Ustawa z 15 kwietnia 2011, art. 3, ust. 1]:

1. publiczne i niepubliczne przedszkola, szkoły i placówki oraz inne jednostki należące do systemu oświaty [Ustawa z 14 grudnia 2016, art. 2];

2. inne jednostki wykonujące zadania z zakresu oświaty:

a. jednostki samorządu terytorialnego;

b. ministrowie prowadzący szkoły i placówki oświatowe;

c. Centralna Komisja Egzaminacyjna;

d. okręgowe komisje egzaminacyjne (dalej: OKE);

e. zakłady poprawcze i schroniska dla nieletnich, a także organy sprawujące nadzór pedagogiczny nad tymi placówkami;

f. kuratoria oświaty;

g. specjalistyczne jednostki nadzoru nad szkołami i placówkami artystycznymi;

h. jednostki obsługujące szkoły i placówki prowadzone przez JST (tzw. samorządowe centra usług wspólnych);

i. izby rzemieślnicze.

Zatem lokalne bazy danych SIO prowadzone są zarówno przez jednostki świadczące usługi edukacyjne (pkt 1), jak i podmioty prowadzące te jednostki (pkt 2, lit. a, b, e, i), obsługujące je (pkt 2, lit. h), nadzorujące je pod względem pedagogicznym (pkt 2, lit. e-g) czy też organizujące egzaminy zewnętrzne (pkt 2, lit. c, d, i).

\section{Zakres informacji o dokonaniach edukacyjnych w SIO}

W świetle definicji dokonań, przytoczonej we wcześniejszej części artykułu, informacje o dokonaniach edukacyjnych są gromadzone w SIO w zbiorach danych o szkołach i placówkach oświatowych, w zbiorach danych o uczniach oraz w zbiorach danych o nauczycielach (tabela 1).

Szczegółowość i terminy przekazywania danych do SIO określa ustawa [Ustawa z 15 kwietnia 2011, art. 8, 10-29, 30, 32, 50] oraz wydany na jej podstawie akt wykonawczy [Rozporządzenie z 29 lipca 2016]. Zakres pomiaru wybranych dokonań szkół i placówek w Polsce został zaprezentowany w tabeli 2.

Przedstawiony zasób informacji gromadzonych w SIO dotyczy dokonań edukacyjnych w trzech obszarach (rys. 2). Analiza dokonań z zakresu oszczędności będzie prowadzona na podstawie informacji o zasobach zaangażowanych $\mathrm{w}$ działalność oświatową (miary niefinansowe) oraz danych o wydatkach na ich pozyskanie (miary finansowe). Pomiar dokonań z obszaru wydajności wykorzystania zasobów szkół i placówek będzie bazować na informacjach o ich działaniach i efektach (miary niefinansowe) odniesionych do odpowiadających im wydatków i kosztów (miary finansowe) poniesionych na ich uzyskanie. Dokonania w zakresie skuteczności będą zaś mierzone w oparciu o informacje o osiągniętych efektach edukacyjnych (miary niefinansowe w SIO) w porównaniu z efektami zakładanymi przez państwo w polityce edukacyjnej lub planowanych przez jednostki oświatowe (informacje spoza SIO). 
Tabela 2. Zakres danych o wybranych dokonaniach jednostek systemu oświaty w Polsce, gromadzonych w lokalnych bazach danych SIO

\begin{tabular}{|c|c|c|}
\hline $\begin{array}{c}\text { Obszar } \\
\text { pomiaru } \\
\text { dokonań }\end{array}$ & $\begin{array}{c}\text { Podmiot prowa- } \\
\text { dzący lokalną bazę } \\
\text { danych SIO }\end{array}$ & $\begin{array}{c}\text { Dane o wybranych } \\
\text { dokonaniach oświatowych }\end{array}$ \\
\hline $\begin{array}{l}\text { Zasoby } \\
\text { (nakłady) }\end{array}$ & \multirow[t]{2}{*}{$\begin{array}{l}\text { Szkoły i placówki } \\
\text { oświatowe prowa- } \\
\text { dzone przez JST, } \\
\text { ministrów } \\
\text { i pozostałe } \\
\text { podmioty }\end{array}$} & $\begin{array}{l}\text { Powierzchnia gruntów i budynków; liczba, metraż i rodzaj pomiesz- } \\
\text { czeń; wyposażenie (m.in. rodzaj i liczba urządzeń sportowych, zbio- } \\
\text { rów bibliotecznych i pomocy dydaktycznych, w tym komputerów, } \\
\text { dostęp do Internetu, korzystanie z dziennika elektronicznego, licz- } \\
\text { ba licencji do e-platform edukacyjnych i e-podręczników, wykaz } \\
\text { obowiązujących podręczników); liczba miejsc w placówce; poziom } \\
\text { dostosowania do potrzeb osób niepełnosprawnych; liczba osób i } \\
\text { wymiar zatrudnienia nauczycieli; wykształcenie i kwalifikacje, sto- } \\
\text { pień awansu zawodowego pracowników pedagogicznych; liczba } \\
\text { planowanych zwolnień nauczycieli w danym roku kalendarzowym; } \\
\text { liczba i wymiar zatrudnienia pracowników niepedagogicznych we- } \\
\text { dług stanowisk }\end{array}$ \\
\hline $\begin{array}{l}\text { Działania } \\
\text { i efekty }\end{array}$ & & $\begin{array}{l}\text { Liczba i rodzaj oddziałów wraz z ich liczebnością; liczba uczniów } \\
\text { (promowanych i niepromowanych; z wydłużonym okresem nauki; } \\
\text { posiadających orzeczenie o potrzebie kształcenia specjalnego; lau- } \\
\text { reatów i finalistów olimpiad i konkursów; korzystających z pomocy } \\
\text { materialnej); spełnianie obowiązku szkolnego i nauki; liczba ab- } \\
\text { solwentów; liczba osób korzystających z dowożenia i z dożywia- } \\
\text { nia; nauka języków obcych; profile kształcenia i zawody; liczba } \\
\text { uczestników kwalifikacyjnych kursów zawodowych; liczba osób } \\
\text { korzystających z biblioteki szkolnej; liczba uczestników zajęć po- } \\
\text { zalekcyjnych; wypadki uczniów; wyniki egzaminów zewnętrznych } \\
\text { prowadzonych przez OKE oraz izby rzemieślnicze }\end{array}$ \\
\hline \multirow[t]{2}{*}{$\begin{array}{l}\text { Wydatki / } \\
\text { koszty }\end{array}$} & $\begin{array}{l}\text { Publiczne szkoły } \\
\text { i placówki oświa- } \\
\text { towe prowadzone } \\
\text { przez JST } \\
\text { i ministrów }\end{array}$ & $\begin{array}{l}\text { Planowane i wykonane wydatki na prowadzenie szkoły lub placów- } \\
\text { ki oświatowej, w szczegółowości do działu, rozdziału i paragrafu } \\
\text { klasyfikacji budżetowej przekazywane do SIO kwartalnie do } 10 . \\
\text { dnia kolejnego miesiąca; wysokość płac nauczycieli wraz ze struk- } \\
\text { turą wynagrodzenia; koszty wynagrodzeń pracowników niepedago- } \\
\text { gicznych wraz z pochodnymi od wynagrodzeń }\end{array}$ \\
\hline & \begin{tabular}{|l|} 
Publiczne i niepu- \\
bliczne szkoły \\
i placówki prowa- \\
dzone przez osoby \\
fizyczne i osoby \\
prawne inne niż \\
JST
\end{tabular} & $\begin{array}{l}\text { Wykonane wydatki na prowadzenie szkoły lub placówki oświato- } \\
\text { wej za okres I-VIII oraz za rok kalendarzowy z wyszczególnieniem } \\
\text { wydatków majątkowych i wydatków na wynagrodzenia, w tym dla } \\
\text { nauczycieli; łączna wysokość otrzymanej dotacji podmiotowej; wy- } \\
\text { sokość przeciętnego wynagrodzenia nauczyciela przypadającego na } \\
1 \text { etat wraz z nieperiodycznymi składnikami wynagrodzenia }\end{array}$ \\
\hline
\end{tabular}

Źródło: opracowanie własne na podstawie [Ustawa z 15 kwietnia 2011, art. 8, 10-29; Rozporządzenie z 29 lipca 2016].

Należy zaznaczyć, iż miary dokonań edukacyjnych z tabeli 2 są przekazywane za pomocą tzw. nowego SIO. Jednocześnie od 30 kwietnia 2012 r. do końca 2017 r. funkcjonuje równolegle tzw. stare SIO, obejmujące nieco inne, choć także obszerne 
dane [Ustawa z 15 kwietnia 2011, art. 105-118]. Zatem od ponad 5 lat zobowiązane podmioty wprowadzają ogromny zasób informacji do dwóch skomplikowanych baz danych $\mathrm{SIO}^{3}$.

\section{Ocena efektywności publicznego finansowania oświaty - w SIO oraz w budżecie zadaniowym}

SIO gromadzi dane niezbędne m.in. „do analizy efektywności wykorzystania środków publicznych przeznaczonych na finansowanie zadań oświatowych" [Ustawa z 15 kwietnia 2011, art. 1]. Przytoczony cel funkcjonowania SIO jest zbieżny z pomiarem dokonań edukacyjnych w obszarze wydajności wykorzystania zasobów (rys. 2).

Analiza szerokiego zakresu danych gromadzonych i przetwarzanych w bazach SIO [Ustawa z 15 kwietnia 2011; Rozporządzenie z 16 lipca 2016] pozwala sformułować wniosek na temat ich wykorzystania do oceny efektywności (rozumianej jako wydajność) publicznego finansowania oświaty: w SIO nie jest prowadzony pomiar wydajności (efficiency) wykorzystania zasobów oświatowych pozyskanych dzięki wydatkom publicznym, gdyż nie występują w nim miary wydajności (efekty w relacji do nakładów lub wydatków/kosztów). Ponadto zgromadzone dane niezbędne do jej pomiaru nie są ze sobą współmierne ${ }^{4}$, co nie pozwala na poprawną metodycznie analizę efektywności wykorzystania środków publicznych. Dlatego nie można nazwać SIO systemem pomiaru dokonań.

Mimo że w samym SIO nie jest prowadzony pomiar dokonań edukacyjnych, to dane gromadzone tam w sposób systematyczny i obowiązkowy mogą być wykorzystane przez inne systemy pomiaru dokonań, np. budżet zadaniowy. Monitoruje on wykonanie zadań (m.in. oświatowych), finansowanych dzięki wydatkom publicznym, przez system mierników ilościowych i jakościowych dotyczących osiągniętych efektów [Filipiak 2011, s. 163]. Poniżej opisano wyniki analizy sprawozdań z wykonania budżetu za 2015 r. w trzech miastach stosujących budżet zadaniowy, pod kątem stosowania mierników realizacji zadań oświatowych opartych na danych SIO.

Dla zadań i podzadań Gdańska w ramach funkcji edukacja i opieka wychowawcza oraz pomoc materialna publikowane są wartości zdefiniowanych mierników oraz finansowe i niefinansowe wielkości statystyczne (np. zadanie 3.1. zarządzanie systemem edukacji w mieście, podzadanie 3.1.2. finansowanie i prowadzenie samo-

3 Tzw. stare SIO miało funkcjonować przejściowo, ale okres jego prowadzenia był wielokrotnie wydłużany, gdyż służy ono - jako system sprawdzony w przeciwieństwie do działającego już od 5 lat (sic!) tzw. nowego SIO - do poprawnego naliczania części oświatowej subwencji ogólnej dla JST na podstawie danych o liczbie uczniów i o etatach nauczycieli. Obecny termin, 31 grudnia 2017 r., wprowadzono ustawą okołobudżetową na 2017 r. [Ustawa z 2 grudnia 2016, art. 16, 21].

${ }^{4}$ Nie można ustalić, które zasoby lub wydatki przyczyniły się do uzyskania poszczególnych efektów edukacyjnych. 
rzadowych szkót i placówek dla dzieci i młodzieży (...) - wybrane mierniki: 30,04\% udziału miasta w całkowitym rocznym koszcie kształcenia 1 ucznia w LO, 7. miejsce Gdańska w rankingu zdawalności matury dla 16 miast wojewódzkich; wybrane wielkości statystyczne: średni roczny koszt utrzymania 1 ucznia LO - 8736 zł, wysokość średniej rocznej dotacji na 1 ucznia w niepublicznym LO dla młodzieży - 5710 zł, średnie zatrudnienie nauczycieli w LO - 607,15 etatów, zaś administracji i obsługi - 210,38 etatów) [Prezydent Miasta Gdańska 2016, s. 276-277].

Sprawozdanie z wykonania budżetu Krakowa zawiera tylko wybrane mierniki realizacji zadań. Dla zadań nadzorowanych przez Wydziat Edukacji są to planowane miesięczne wydatki przypadające na 1 ucznia danego typu szkoły lub placówki (np. 632,58 zł w szkole podstawowej, 732,38 zł w gimnazjum) [Prezydent Miasta Krakowa 2016, s. 137]. Warto dodać, że mierniki są prezentowane inaczej niż w Gdańsku i Szczecinie, tj. osobno od zestawienia i opisu wykonania wydatków dla zadań.

Opis wydatków Szczecina w układzie zadań dla sfery edukacja $i$ nauka zawiera finansowe i niefinansowe mierniki ich realizacji (np. pomoc materialna dla uczniów - 729 przyznanych stypendiów naukowych o średniej wartości 371 zł, 3150 przyznanych stypendiów socjalnych o średniej wartości 120 zł) [Prezydent Miasta Szczecin 2016, s. 402-403].

Podsumowując przeprowadzoną analizę, należy stwierdzić, iż omawiane miasta przyjęły zróżnicowaną szczegółowość prezentacji mierników realizacji zadań oświatowych, jednak w żadnym z nich nie podano SIO jako źródła danych.

\section{Zakończenie}

Działający obecnie system informacji oświatowej (tzw. nowe, jak i tzw. stare SIO) nie spełnia funkcji systemu pomiaru dokonań edukacyjnych ani nie stanowi źródła danych dla innych instrumentów pomiaru dokonań, np. dla budżetu zadaniowego.

Trudności w dostosowaniu SIO do roli systemu pomiaru dokonań oświatowych wynikają m.in. z bardzo szerokiego zakresu gromadzonych danych i ze słabej jakości rozwiązań informatycznych (bezpłatne oprogramowanie zapewniane przez MEN). Warto pamiętać, iż wdrożenie nadmiernie rozwiniętego i skomplikowanego systemu ze zbyt dużą liczbą wskaźników może spowodować skupienie uwagi zarządzających jedynie na ich analizie i ocenie zamiast na bieżących i strategicznych problemach decyzyjnych [Kowalewski 2011, s. 256].

\section{Literatura}

Buk H., Kostur A. M. (red.), 2009, Zintegrowany system pomiarów dokonań w rachunkowości. Księga pamiątkowa wydana z okazji 60-lecia obecności prof. zw. dra hab. Zbigniewa Messnera w Akade- 
mii Ekonomicznej im. Karola Adamieckiego w Katowicach, Wydawnictwo Akademii Ekonomicznej w Katowicach, Katowice.

Filipiak B., 2011, Budżet zadaniowy jako instrument pomiaru dokonań w jednostkach samorzadu terytorialnego, Prace Naukowe Uniwersytetu Ekonomicznego we Wrocławiu, nr 182, s. 160-168.

Kotłowska M., Kowalak R., 2016, Kluczowe mierniki dokonań w zarządzaniu przedsiębiorstwem, Wydawnictwo Uniwersytetu Ekonomicznego we Wrocławiu, Wrocław.

Kowalewski M., 2011, Ewolucja i rola systemów pomiaru dokonań w zarządzaniu przedsiębiorstwem, Prace Naukowe Uniwersytetu Ekonomicznego we Wrocławiu, nr 182, s. 248-258.

Napiecek R., 2013, Rachunek kosztów w zrównoważonej ocenie dokonań uczelni wyższej, Wydawnictwo Uniwersytetu Ekonomicznego w Poznaniu, Poznań.

Nieplowicz M., 2011, Rozważania o miernikach w kontekście pomiaru dokonań w miastach na przykładzie wybranych ustug technicznych, Prace Naukowe Uniwersytetu Ekonomicznego we Wrocławiu, nr 182, s. 355-363.

Prezydent Miasta Gdańska, 2016, Sprawozdanie z wykonania budżetu Miasta Gdańska za rok 2015, Gdańsk, http://www.infor.pl/akt-prawny/U79.2016.100.0002308,sprawozdanie-prezydenta-miasta-gdanska-z-wykonania-budzetu-miasta-gdanska-za-2015-rok.html (26.03.2017).

Prezydent Miasta Krakowa, 2016, Sprawozdanie z wykonania budżetu Miasta Krakowa za rok 2015, Kraków, https://www.bip.krakow.pl/zalaczniki/dokumenty/n/155017/karta (26.03.2017).

Prezydent Miasta Szczecin, 2016, Sprawozdanie z wykonania budżetu Miasta Szczecin za rok 2015, Szczecin, http://bip.um.szczecin.pl/chapter_50934.asp?soid=437039605D5E49268BB8FDE5F6F 421D5 (26.03.2017).

Rozporządzenie Ministra Edukacji Narodowej z 29 lipca 2016 r. w sprawie szczegółowego zakresu danych dziedzinowych gromadzonych w systemie informacji oświatowej oraz terminów przekazywania niektórych danych do bazy danych systemu informacji oświatowej, Dz.U. z 2016, poz. 1267.

Ustawa z 2 grudnia 2016 r. o szczególnych rozwiązaniach służących realizacji ustawy budżetowej na rok 2017, Dz.U. z 2016, poz. 1984.

Ustawa z 14 grudnia 2016 r. Prawo oświatowe, Dz.U. z 2017, poz. 59.

Ustawa z 15 kwietnia 2011 r. o systemie informacji oświatowej, tj. Dz.U. z 2016, poz. 1927 ze zm.

Ustawa z 27 sierpnia 2009 r. o finansach publicznych, tj. Dz.U. z 2016, poz. 1870 ze zm. 